\title{
RECLAMATION OF DISTURBED LANDS IN GLEN CANYON NATIONAL RECREATION AREA
}

\author{
Cyrus M. McKell \\ School of Natural Sciences \\ Weber state College \\ ogden, UT
}

\section{Introduction and objectives}

Successful establishment of vegetation in regions such as the Glen Canyon National Recreation Area (NRA) requires the most favorable sequence of weather events possible. In addition to favorable weather, soil conditions must be such that transplanted roots are placed in contact with moist soil and can rapidly grow out into the surrounding area (unrestricted by compaction). Only infrequently do plants establish naturally from seeds in the harsh conditions of the Glen Canyon NRA. Thus, the objectives for the study were to review the literature on artificial revegetation in arid regions and to establish test plots in accord with current weather conditions, especially with regard to periods of drought or precipitation.

The fall of 1989 was very hot and dry and as a result, establishment of field plots would have been difficult and probably worthless because of sure failure. Subsequently, plans have been made for construction of plots in late March on the assumption that a period of precipitation will occur that will adequately wet the soil root zone.

This report covers project activities to the end of December. These activities primarily deal with field sites selection and propagation of plants for planting in late winter or spring 1990.

\section{Methods}

Upon award of this project, contact was made with National Park Service staff at Glen Canyon NRA at Paige, Arizona and arrangements made for a site visit. Arrangements were made with Charles Wood and John Ritenhour to visit Paige and Hall's Crossing marinas on August 4, 1989. As a result of this visit, plot sites were tentatively located near the view outlook approach to the dam area at Paige and on an abandoned 
road near a former disposal area at Hall's crossing marina. Both sites represent a number of disturbed areas that should be revegetated. Field plot results should be applicable to many of the disturbed sites in Lake Powell NRA.

In the review of possible field sites at Paige, soil compaction caused by heavy equipment, appeared to have caused unfavorable conditions for natural establishment of vegetation. To determine the extent of compaction, a cursory survey was made using a hand shovel and observing the compaction layers and their depth. In a report to John Ritenhour (Appendix 1), the gravelly nature and depth to compaction were described as severe. Thus, some type of ripping would be necessary prior to planting. In a subsequent telephone conversation with Charles Wood, he agreed to have a study site "ripped" in order to break-up the compacted layer. Because of continued dry conditions during the late fall, no planting could be attempted and ripping would be done as soon as sufficient precipitation occurs in the winter to wet the soil. No anticipated problem with dense compaction is expected at the Hall's crossing site because of the sandy nature of the soil. However, it is essential that the soil be moist prior to planting.

Because of the commercial unavailability of native plants to establish in the study sites, propagation of the appropriate plant materials is necessary. Accordingly, a native seed company (Granite seed Company of Lehi, Utah) was contacted for species available in their inventory. one-pound lots of the following species were purchased:

\section{Grasses}

Indian Ricegrass

Sand dropseed

Galletta grass

\section{Forbs}

Desert mallow Low desert mallow Desert marigold Globe gillia

\section{Shrubs}

Fourwing saltbush Shadscale Winterfat Nevada ephedra
Oryzopsis hymenoides Sporobolus criptandrus Hillaria jamesii

Sphaeralcea grossulariafolia Sphaeralcea ambiqua Baileya multiradiata Gillia capitata

Atriplex canescens Atriplex confertifolia Ceratoides lanata Ephedra nevadensis 
Arrangements were made with a native plants nursery to provide in late March plants of Utah juniper (Juniperus osteosperma) and Big Sagebrush (Artemisia tridentata) that have been propagated from seed sources collected in southern Utah.

From 40 to 60 plants of most seeds have been propagated in the WSC Botany Department greenhouse from the above seed lots, with the exception of shadscale and Indian ricegrass. Seeds of these species are difficult to germinate because of hard seedcoats and dormancy. As an alternative, plants of Indian ricegrass have been cloned from a collection of bunches obtained from a sandy soil near santa Clara Utah.

Plans are underway to propagate plantlets from stem cuttings of blackbrush (Coleogyne ramosissima) from a site in southern Utah similar to the NRA study sites. These plant materials will be ready for outplantings in late March.

\section{Plans and Schecule for Completion of Project}

Because of the very dry autumn of 1989 prudence required that establishment of field plots be deferred until late winter or early spring of 1990. This was discussed with Charles Wood in early December 1989. Recognizing that the field plot locations and the relevant areas they represent are in a climatic region that averages 6 inches annual rainfall (Lee's Ferry) it is essential to schedule planting operations after a period of rain or snow that is sufficient to wet the soil deep into the root zone. This rule-of-thumb was developed from extensive field trials in the colorado plateau region over several years of work on sites disturbed by coal mining, pipeline rights-of-way, oil and gas exploration, oil shale development and rangeland improvement (McKell 1978, McKell and Van Epps 1981, and Van Epps and McKell 1983).

An associated commitment of the project proposal was to do a 15-year follow-up plot analysis of revegetation test plots established in 1975 on Wildcat Mesa on the west side of the Henry Mountains which were part of an Energy Management Resource Inventory Assessment (EMRIA) study on BLM lands in the Henry Mountains. Again, because of very dry conditions in the fall of 1989, it appeared provident to defer assessment of plant survival on the six Henry Mountain plots until spring.

Under the expectation of reasonable precipitation in December, January, February, and early March the field work will be accomplished. Tentatively, the week of March 19 has been reserved for: 
a. Field plot establishment at Paige view site

b. Field plot establishment at Hall's Crossing disposal area

c. Survival analysis of field plots at Henry Mountains

Preparation of the project report will be done in April and a draft submitted for review on May 30. This report will include the following:

1. Field plot designs, including species and treatments

2. Plant survival data from Henry Mountains showing the long term survival of native plant transplants in the general area on various soil/substrates

3. Literature review of date, plots, writings on reclamation for the arid region represented by Glen Canyon NRA

\section{Literature Cited}

Van Epps, Gordon A. and Cyrus M. McKell. 1983. Effects of weedy annuals on the survival and growth of transplants under arid conditions. J. Range Manage. 36:366-369.

McKell, Cyrus M. and Gordon A. Van Epps. 1981. Comparative results of shrub establishment in arid sites. pp. 138154 In Shrub establishment on disturbed arid and semi arid lands. Wyo. Game and Fish Dept.

McKell, C.M. [ed.]. 1978. Rehabilitation potential of the Henry Mountain coal field. U.S. Dept. Interior, BLM. EMRIA Report No. 15. 277pp. 